\title{
Pleasure and suffering in the work of nurses at the oncopediatric hospital unit: qualitative research
}

\author{
Prazer e sofrimento no trabalho dos enfermeiros da unidade de internação oncopediátrica: pesquisa qualitativa
}

Placer y sufrimiento en el trabajo de los enfermeros de la unidad de internación oncopediátrica: investigación cualitativa

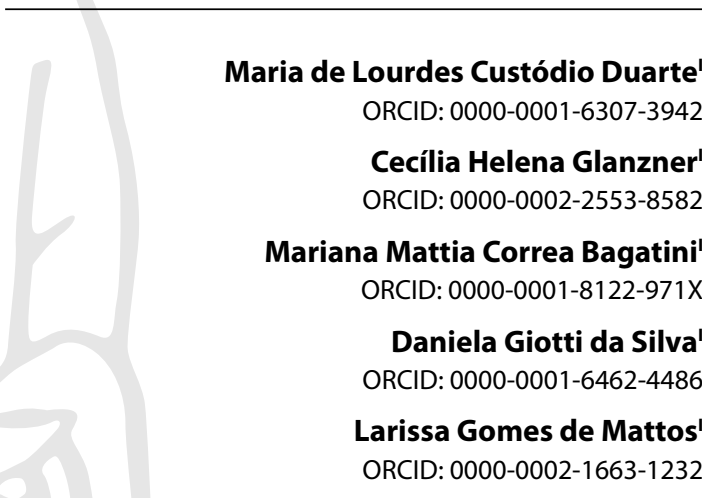

'Universidade Federal do Rio Grande do Sul. Porto Alegre, Rio Grande do Sul. Brazil.

How to cite this article:

Duarte MLC, Glanzner CH, Bagatini MMC, Silva DG, Mattos LG. Pleasure and suffering in the work of nurses at the oncopediatric hospital unit: qualitative research. Rev Bras Enferm. 2021;74(Suppl 3):e20200735. http://doi.org/10.1590/0034-7167-2020-0735

\section{Corresponding author:}

Maria de Lourdes Custódio Duarte

E-mail:malulcd@yahoo.com.br

EDITOR IN CHIEF: Antonio José de Almeida Filho ASSOCIATE EDITOR: Fátima Helena Espírito Santo

Submission: $07-28-2020$

Approval: 10-14-2020

\section{ABSTRACT}

Objective: To analyze the experiences that generate pleasure and suffering in the work of nurses in an oncopediatric inpatient unit. Methods: Qualitative, exploratory, descriptive study. Data collection took place from March to May 2018, through interviews with eight nurses in an oncopediatric inpatient unit. Results: The verbalized experiences of pleasure were the work developed with children, participation in the treatment and cure of patients and the recognition of family members in relation to the work performed. The suffering experiences were palliative care and death of patients, performing invasive procedures and organizing work. Final considerations: It was possible to analyze the experiences of pleasure and suffering of nurses in an oncopediatric unit through the psychodynamics of work, allowing to reinvent prevention and intervention measures by managers in health/mental illness processes at work. Descriptors: Nursing; Work; Neoplasms; Paediatrics; Pleasure.

\section{RESUMO}

Objetivo: Analisar as vivências geradoras de prazer e sofrimento no trabalho de enfermeiros em uma unidade de internação oncopediátrica. Método: Estudo qualitativo, do tipo exploratóriodescritivo. A coleta de dados ocorreu de março a maio de 2018, por meio de entrevistas com oito enfermeiros em uma unidade de internação oncopediátrica. Resultados: As vivências de prazer verbalizadas foram o trabalho desenvolvido com crianças, a participação no tratamento e cura dos pacientes e o reconhecimento dos familiares em relação ao trabalho realizado. As vivências de sofrimento foram os cuidados paliativos e morte dos pacientes, realização de procedimentos invasivos e organização do trabalho. Considerações finais: Foi possível analisar as vivências de prazer e sofrimento de enfermeiros em uma unidade oncopediátrica por meio da psicodinâmica do trabalho, permitindo reinventar medidas prevenção e intervenção dos gestores nos processos de saúde/doença mental no trabalho. Descritores: Enfermagem; Trabalho; Neoplasias; Pediatria; Prazer.

\section{RESUMEN}

Objetivo: Analizar las vivencias generadoras de placer y sufrimiento en el trabajo de enfermeros en una unidad de internación oncopediátrica. Método: Estudio cualitativo, del tipo exploratorio-descriptivo. La recogida de datos ocurrió de marzo a mayo de 2018, por medio de entrevistas con ocho enfermeros en una unidad de internación oncopediátrica. Resultados: Las vivencias de placer verbalizadas han sido el trabajo desarrollado con niños, la participación en el tratamiento y cura de los pacientes y el reconocimiento de los familiares en relación al trabajo realizado. Las vivencias de sufrimiento han sido los cuidados paliativos y muerte de los pacientes, realización de procedimientos invasivos y organización del trabajo. Consideraciones finales: Ha sido posible analizar las vivencias de placer y sufrimiento de enfermeros en una unidad oncopediátrica por medio de la psicodinámica del trabajo, permitiendo reinventar medidas de prevención e intervención de los gestores en los procesos de salud/enfermedad mental en el trabajo.

Descriptores: Enfermería; Trabajo; Neoplasias; Pediatría; Placer. 


\section{INTRODUCTION}

Considering the relevance of work for men and changes in the work environment, it is understood that the productive activity can reflect positively or negatively on the worker's health ${ }^{(1)}$. Work is a means by which the subjects find themselves relating to the external environment, being of great importance for the analysis of the human being and his relationship with the material and psychic world in the search for the balance between pleasure and suffering ${ }^{(2)}$.

Pleasure can manifest itself as a beneficial feeling related to the psychological stability of the worker from the moment they overcome the difficulties imposed by the work, through acquired skills and actions of solving in his professional environment ${ }^{(3-4)}$. Suffering, in turn, is considered an unpleasant emotional experience associated with feelings such as fear, worthlessness, impotence, dissatisfaction, stress, among others. Thus, the conditions and organization of work linked to the characteristics of people can result in the appearance of suffering ${ }^{(5)}$.

In the context of health work, nursing performs functions in which pleasure and suffering coexist in their care activity. In more specific areas, such as oncopediatric inpatient units, nursing care for these children is a complex task, as it encompasses various feelings influenced by elements such as the improbability of a cure, the frustration of the life perspective that is expected for a child and the expectation of the death of a helpless being in need of protection ${ }^{(6)}$.

Thus, nurses may present obstacles in their work routine in pediatric oncology due to the manifestation of pain, suffering and death of the sick child. In this context, understanding the pain of children and family members who experience prematurely becoming ill and dying can represent a stressful experience of suffering for professionals ${ }^{(6)}$.

In addition, some work-related experiences can be harmful to the worker, such as the particularities of organizations in the health environment, constant and high psychological demands, habitual performance issues, scarce number of workers and alternation in the investigated working hours ${ }^{(6)}$.

In addition, some work-related experiences can be harmful to the worker, such as the organizational characteristics of the health environment, constant and high mental demands, routine performance issues, insufficient number of human resources and alternation in the investigated work shifts ${ }^{(7-8)}$.

Considering these aspects, the theoretical framework of work psychodynamics (WPD), idealized by the French psychiatrist Christophe Dejours, who emphasizes the study of the dynamic relationships between work organization and the subjective and intersubjective processes that arise from the relationship between the psychic organization of people with the labor process, can contribute to the understanding of this context ${ }^{(5)}$.

In this sense, there is a growing interest of researchers in the suffering-pleasure relationship and the organization of nursing work, especially in intensive care units, in emergency and oncological services ${ }^{(2,8-9)}$. Keeping an eye on the team can favor the existence of pleasure in the work environment. So, recognizing the origins of the professionals' pleasure can help the manager to carry out activities that qualify the work, allowing the worker to achieve pleasure in their daily lives ${ }^{(10)}$.
Pointing to the growing need for health care for workers, especially those in the area of pediatric oncology, due to the strong emotional load to which they are subjected daily, it is expected, with this study, to analyze the work in this area, in the light of the WPD. It also aims to expand the reflection on the satisfaction of the staff of a pediatric oncology unit, taking into account experiences that generate pleasure and suffering.

The study proves to be pertinent, as it is considered that the quality of care offered to children is directly associated with the well-being of professionals in the work environment. Such quality encompasses not only tangible aspects, but especially subjective factors related to mental health, which are often not seen by workers and managers.

Therefore, the question is: What are the experiences that generate pleasure and suffering in the work of nurses in an oncopediatric inpatient unit?

\section{OBJECTIVE}

To analyze the experiences that generate pleasure and suffering in the work of nurses in an oncopediatric inpatient unit.

\section{METHODS}

\section{Ethical aspects}

The study was approved by the Research Ethics Committee (REC) of the health institution where the study was conducted and complied with Resolution 466/2012, of the National Health Council ${ }^{(11)}$. Participants were provided with the Free and Informed Consent Form (ICF), with a copy of the same content with the interviewee and another with a researcher.

\section{Study type}

Qualitative, exploratory-descriptive study ${ }^{(12)}$, guided by the Standards for Reporting Qualitative Research instrument (SRQR) ${ }^{(13)}$, with the objective of strengthening methodological rigor. Qualitative research has the peculiar characteristics of apprehending questions, making it possible to answer the fundamentals of the object of study. Its wide approach has several meanings, which allow to glimpse perceptions, perspectives, narratives, ideologies, behaviors, which cannot be reduced to variables and their intrinsic modes of execution ${ }^{(12)}$.

\section{Methodological procedures}

\section{Study scenario}

The research was carried out in a Pediatric Oncology Inpatient Unit of a university hospital in the south of the country, with 25 beds. The age group served is from 28 days to 18 years of age. Due to the high complexity of the children attended, it is considered a semi-intensive hemato-oncological care unit, covering the stages of cancer treatment and in terminally ill patients.

\section{Data source}

The team is composed of 14 nurses. These are divided into three nurses in the morning, three in the afternoon and two 
during the night (the night shift is divided into Night 1, Night 2 and Night 3) and two nurses on duty on weekends and holidays.

Nurses who work in the care of pediatric oncology patients admitted to the oncopediatric inpatient unit of the hospital were invited to participate in the research. Its inclusion criteria were: working for at least six months in the care of pediatric cancer patients undergoing treatment at the oncopediatrics unit; accept the invitation to participate in the study; and be working during the time of data collection. In the present study, there were no exclusions of participants, as all 14 nurses in the unit met the inclusion criteria and accepted to participate in the research and sign the ICF.

It is understood that the professionals who have worked for at least six months in the unit can contribute more comprehensively to the reflections on the topic under study, considering their experiences at work.

The selection of study participants was intentionally defined, scholars were able to define the election of workers, considered typical of the population or knowledgeable about the topic to be researched, according to the study's information needs.

Eight nurses participated in the research, including one professional from each work shift. Data were collected individually using the semi-structured interview technique, consisting of open and closed questions about the experiences of pleasure and suffering in patient care in the pediatric oncology unit.

\section{Data collection and organization}

Data collection took place during the months of March to May 2018 , by scheduling according to the availability of the participants. The interviews were carried out by the responsible researcher, in a different shift from the one in which the professional works, in a place scheduled in the studied hospital, and were recorded on audio equipment (MP3) with an approximate duration of 30 minutes and later transcribed in full for better understanding of the material.

The questions that guided the interview were: What are the factors that generate pleasure and suffering at work for you? What are your feelings in the face of a situation of suffering and pleasure? Faced with a situation of suffering experienced in your work environment, what do you do to alleviate it? What motivates you to work in the paediatric oncology unit?

The interviews were identified with the letter $E$ for a nurse, followed by the number representing the order in which they occurred: E1, E2 and, so on, successively.

\section{Data analysis}

Thematic content analysis technique was used, guided by Minayo (12), which was divided into three phases: 1) Pre-analysis - It consisted of the organization of the materials that were analyzed through a floating reading of the set of information, the constitution of the corpus, as well as the resumption of the purposes and definition of markers to guide the final reflection. This step allows the alignment of interpretations and the emergence of new questions; 2) Exploration of the material - The classification and aggregation of the information worked in the text clippings of the information units occurred, defining the categories based on the most relevant elements found in the participants'statements. 3) Treatment of the results obtained and interpretation - The data were submitted to a procedure that allowed to highlight the results found, so the search focused on ideologies, trends and other characteristics that were analyzed, interpreted and based on the literature ${ }^{(12)}$.

After analyzing the information, two analytical categories emerged: Pleasure of the nursing team in patient care in paediatric oncology; and Suffering of the nursing team in patient care in paediatric oncology.

The analysis and discussion of the results were carried out in the light of the psychodynamics of work, proposed by Dejours.

\section{RESULTS}

As for the characterization of the research subjects, there were eight female nurses, and the average age was 54 years. Regarding the time since graduation, the average found was 25 years, and the time in the paediatric oncology area varied between 7 and 25 years. It was found that $50 \%$ of the nurses interviewed have some specialization, however none in the area of paediatric oncology. Three (37.5\%) of the interviewees also work at another health institution.

\section{Pleasure of the nursing team in patient care in paediatric oncology}

In this category, the interviewed subjects stated that the work developed with children, participation in the treatment, the healing of patients and the recognition of family members in relation to the work performed allow them to experience pleasure in the oncopediatric unit.

Such experience appears directly associated with child-care, especially through the affection received and the bond created that remains even after discharge, when many families return to the unit to find the workers again.

I think the very fact of taking care of children is already pleasurable. I have worked with adults, the elderly, but I always preferred to work with paediatrics. This disease punishes a lot, so when they are well and return to see us it is very pleasant. Seeing them running, playing, that's good. (E1)

I like children very much in general, I like this interaction, I think it's a great energy that they have, even when they are not well [...]. (E6)

Nursing, as a professional category that is in direct and constant contact with patients and their families, assumes a fundamental role in maintaining this relationship, establishing links and integrating the various support sectors in child care. Given the circumstance, despite living with situations of suffering and death, the clinical progress of the hospitalized child and its progress are aspects that generate pleasure and satisfaction, since the favorable results seen in these patients are motivating for these workers. Therefore, it is observed that nurses experience pleasant circumstances, overcoming the pathogenic aspects of the work environment.

After you enter paediatric oncology, you fall in love with the service and you don't want to leave here anymore, because it is very pleasant to see a child cured, and we see several. We think that it only deals with death; no, we have the victories, and this causes a lot of pleasure. (E3) 
Certainly, feeling that I can make a difference... children and teenagers are extremely receptive to the care we give them. They perceive this affection, this care and feel welcomed, feel protected and trust us. (E8)

Nurses point out that paediatrics is a singular unit whose object of care involves the emotion of the worker; therefore, the professional must build a certain profile in the assistance, which does not only involve their technical skill, but also the development of holistic care, with attitudes that include patience, attention and affection for children and their families. Therefore, liking what you do contributes to humanized care, resulting in good professional performance and generating satisfaction for the assistance provided.

The recognition by patients and family members was also another experience that generates satisfaction and pleasure in the daily work of the interviewees, as it validates their work and reinforces their professional identity.

The pleasure is when you see that the mothers hearyou, follow the guidelines, that they understand, because we are always guiding [...] I have wonderful experiences of mothers who meet me in the hospital lobby... when they come to the clinic, they thank and say that, at home, they continue to do the guidelines. (E6)

The care process is reciprocal and exchange; this requires availability, trust, receptivity, and acceptance from both parties, that is, the team and family. The recognition has an impact on the appreciation of the effort and suffering invested in the provision of care and has a direct impact on the construction of the worker's identity, as the efforts made in the work practice acquire meaning, and the professional shows that not only collaborated, but obtained a return for your work. Thus, part of the suffering is transformed into pleasure, avoiding the professional's illness.

\section{Suffering of the nursing team in patient care in paediatric oncology}

In this category, the interviewees were able to verbalize that the care of children undergoing palliative treatment and the death of patients, the performance of invasive procedures and the organization of work were understood by the interviewed workers as sources of suffering.

The moment of the child's finitude in palliative care often happens in the hospital environment, so that the team, previously dedicated to the maximum of curing the disease, is faced with the terminality and the pain of the family. This fact requires workers, in addition to technical and scientific knowledge, considerable emotional preparation to help families face this moment.

When they come for palliative care, the final stage of the disease, this is verystressful for us, they come to control the pain, they go home and return, they cannot control the pain and then they startreceiving Enteral Nutrition [EN], they can't go home anymore, they end up dying. This is very painful, but we keep trying to give a minimum of comfort. (E1)

Death causes suffering. When the patient becomes palliative, we suffer together with the family. (E3)

Based on these reports, it is identified that the patient's suffering and death are difficult factors to be faced in the work activity and that the interest of the worker is to remedy the health difficulties and meet the demands of the inmates. However, when this does not happen, they feel powerless and frustrated. These aspects reflect strongly on the team, as it is their professionals who end up making a closer relationship with patients, manipulating their bodies, routinely observing their wear and tear.

Thus, in view of the impotence to cure, nurses mentioned the opportunity to provide comfort for children hospitalized within their means, easing the pain of the other. In this sense, the performance of invasive procedures was also understood by the interviewees as an experience that generates suffering, since it is potentially triggering pain in hospitalized children, but necessary for the treatment to continue.

When I can't puncture a vein because sometimes we fail, when there is a catheter that is very difficult to puncture in obese patients, it causes me suffering. Performing two intramuscular injections, when you have asparaginase - a medication that is essential in Leukaemia - is very painful for patients. (E2)

Despite the nurses' challenge to take care of a child through invasive and painful procedures, the pathogenic dimension of doing this can make workers sick, who, in their daily lives, experience activities in relation to which they have no autonomy over the decision to do or not to do a technique. Thus, it is understood that there are impositions of technical and scientific domain that are placed in the experience of the work of these professionals at a time of great physical fragility (especially) of the patients and psychic of these workers.

In addition, the paediatric oncology unit has organizational characteristics that promote the experience of negative feelings on the part of nurses, leading them to work suffering. Issues involving the team and bureaucracy in carrying out the service were highlighted, in addition to the organization of work in the unit studied, creating an overload on workers.

Sometimes, the technician falls short in the assistance; what makes me more uncomfortable is managing the nursing team. (E4)

Double duty, you have to do the same thing two or three times. You have to write down in your notebook everything you did, to pass it on to the colleague of the day. You still have to write down everything you did in the notebook, from the notebook to the folder. You still have to go to the computer to evolve everything you did in the notebook. So the same information you will do three times, to do a job well done. (E8)

I think we even have a good number of nurses, but when that number for some time decreases, even on vacation or on leave, when we are in a smaller number, it becomes difficult. This demands too much of us, and it is complicated. Several people end up walking away due to stress, tiredness, depression. (E7)

The requirements for numbers, indicators, goals, and work organization eventually have a compensation in guaranteeing the conditions of materials and personnel necessary for the provision of quality care. These issues and the pathogenic dimension of work are emerging as a challenge, which can cause suffering in professionals in these places. 
The organization of work in the oncopediatric unit studied can hinder micro-creations in the professionals' work experiences, making them feel uncomfortable to express their creativity in an adverse context.

\section{DISCUSSION}

\section{Pleasure of the nursing team in patient care in paediatric oncology}

Obtaining pleasure in the work environment is a subjective experience and is related to the use of intelligence, initiative, creativity, autonomy and the possibility of expression, which enables the valorization and recognition of professional identity ${ }^{(14-15)}$.

If linking the professional with the organization of activities is beneficial, work can be a reason for pleasure and satisfaction. For the worker to experience this pleasure at work, it is essential that the demands of the activity can express their subjectivity, participating in the choice of work rhythm and allowing flexibility according to their own will ${ }^{(5)}$.

The interaction with the child is part of the duties of the nursing team in pediatric oncology, through affection, affinity, interaction, closeness and bonds of friendship, which are defined mainly by the long stay in the hospital environment ${ }^{(14)}$.

Unlike other circumstances, in which health professionals are instructed to avoid involvement and to contain their feelings, in the onco-pediatric unit there is a greater receptivity for their expression towards children and their families.

Thus, these bonds produced tend to be preserved, as mothers commonly return to the institution to visit professionals, even in situations where their children have died or completed treatment, which is a reality in the investigated context. In this scenario, the pleasure-generating relationship remains even after the completion of therapy, when the family visits the service to review the worker or even when they remember those who assisted them, which may generate the perception of satisfaction, of being providing a good service, although there are other difficulties present ${ }^{(7)}$.

Thus, pleasure in the work environment is felt by the creation of satisfaction and the opportunity to promote personalized care, which strengthens the professional's autonomy to organize and perform the work, enabling the discovery of activities and actions with the aim of generating pleasure. Working with children makes it possible to use creativity and organize work in different ways, depending on subjective and objective issues ${ }^{(6)}$. Participation in the treatment and cure of the patient are other conditions that generate pleasure and satisfaction, since favorable outcomes are encouraging. It is noticed that the rehabilitation of the patient generates contentment, especially in those who collaborate properly for this to happen, such as the nursing team ${ }^{(16)}$.

The feelings of satisfaction and gratification appear when the professional understands the restoration of the patient's health as a consequence of the nursing interventions, during the hospitalization period. It is considered that care does not occur in an isolated way, being an interactive process, requiring availability, trust, receptivity and acceptance ${ }^{(16)}$.

In this sense, it is possible to understand the recognition of the work carried out in oncopediatrics by family members and patients themselves. Recognition is considered the dimension of sublimation linked to the judgment of utility, which can also occur from the beneficiary of the quality of work, that is, patients and family members. For the psychodynamics of work, when the quality of work is recognized, the efforts, anxieties, doubts, disappointments and discouragements of workers are given meaning ${ }^{(17)}$.

When the worker is recognized, he perceives the result of his contribution in caring for an oncological child, his valorization by the collective, which is fundamental for his professional identity. In addition, there is a finding that the work is not limited to material or quantifiable solutions, but rather has a larger proportion, which is difficult to see or can be apprehended by conventional evaluation methodologies ${ }^{(7,17)}$.

\section{Suffering of the nursing team in patient care in paediatric oncology}

Suffering arises when the worker has difficulties in balancing or balancing personal needs and expectations in relation to the objectives, situations and working conditions to which they are subjected, with no space to develop their potential as a worker ${ }^{(5)}$.

The work activity of professionals working in the oncology area is constantly permeated by situations involving pain, death and suffering, both for the cancer patient (diagnosis, treatment, prognosis etc.), and for the patient's family in the process of monitoring - not to mention, of course, the demands of nature and work organization ${ }^{(18)}$.

Professional training in health is still guided by the curative logic, which helps workers to experience feelings of helplessness when they are not able to change the patient's critical situation ${ }^{(19)}$, making death a factor that generates suffering and difficult for nursing professionals ${ }^{(20)}$. It is noteworthy that, in this study, no worker had specific training in the area of paediatric oncology, and this may result in a lack of preparation to deal with the emotions and feelings arising from the finitude of a child's life.

Death, for many people, is a subject accompanied by embarrassment, which reveals the complexity of people in facing this issue as a natural biological process. At the moment when the end of childhood life is discussed, death is seen as a major tragedy. This scenario seems to go against what society assumes as an admissible reality, and it is difficult to understand that the life cycle can be reversed ${ }^{(21-22)}$.

Palliative care in the context of oncopediatrics requires from the professional scientific knowledge, technical and interpersonal skills to assess and promote adequate pain relief. Thus, the worker needs to consider pain as something that guides the care offered to children in this context, in order to ease the patient's suffering and assist in decision making ${ }^{(23)}$.

In this context, the process of hospitalization of children with cancer problems is configured as a negative experience for the life of the hospitalized child. They experience difficult moments and situations that range from simple procedures to other invasive, aggressive and painful ones ${ }^{(22-24)}$. Such procedures generate suffering for the worker who works in the oncopediatric inpatient unit studied; even though they have considerable experience in the area, these professionals continue to empathize with the suffering of these children as if they were their own family members.

In addition, the organization of work was also identified by the interviewees as a source of suffering, generating overload. This reality, 
caused by the lack of human resources and high demand for nursing work, is an experience that generates suffering at work, since the excess of activities is now divided between available and tired workers. Thus, the care for hospitalized children can be impaired, characterizing a stressful work situation and contributing to the removal of workers, whether due to stress, tiredness and/or depression.

In this sense, one of the factors for the occurrence of the worker's suffering is due to the space between the prescribed and the real work. The prescribed work comprises the execution of the activity to be performed, guided by guidelines previously established by the organization and following a conventional context, without considering the variables that arise in the occupational routine. Real work, on the other hand, represents situations that are not operationalized in the prescribed work, situations that happen unexpectedly in the act of performing the task, that is, what the worker actually performs ${ }^{(5)}$.

From this perspective, nurses are often pressured to carry out their work automatically, with no opportunity to analyze the care provided, in a way that compromises the care provided to patients and generates suffering in the worker. In this logic, the conditions and organization of work directly impact the quality of care and the health of the professional, since the former impair the health of the worker's body and the latter acts on the level of psychic functioning. Thus, the more regulating and inflexible the labor systematization, the more it will contribute to the worker's psychological suffering ${ }^{(16)}$.

The organization of work is interpreted as the division of labor, the content of tasks, the hierarchical system, management modalities, power relations and responsibilities. In this way, work overload has a social origin, is imposed by the organization of work, without taking into account the wishes or conditions of the worker. When the worker cannot print his rhythm, subjectivity and practical intelligence in professional activities, a submissive and less active characteristic in the work context is printed ${ }^{(25)}$.

\section{Study limitations}

The study is innovative in its conception; however it comes from the experiences of nurses from a specific oncopediatric hospitalization unit, not including other members of the nursing team or even the multidisciplinary team, which would contribute to a better understanding of this phenomenon. New studies are suggested that address such perspectives in order to expand the discussion based on the psychodynamics of work framework.

\section{Contributions to the field of nursing, health or public policy}

The results of this study offer information that makes it possible to reflect on the reality of the work context that many nurses experience. In this way, the experiences of pleasure and suffering reported here provide an opportunity for these actors to reflect and verbalize about their professional activity, generating implications for the way tasks are performed. In addition, they allow discussion in the sense of seeking the well-being of these professionals, going beyond the geographical space in which they work, aiming at their mental health. In this sense, the psychodynamics of work contributes to bring up the reality in an oncopediatric inpatient unit, since the daily work with children suggests a great physical demand and mainly psychic.

\section{FINAL CONSIDERATIONS}

With the study, it was possible to answer the guiding question and the proposed objectives. Nurses who work in pediatric oncology experience experiences of pleasure and suffering arising from their work. The particularities of childcare and nurses who work in this specialty were highlighted.

It is noted that the workday of these professionals is equally surrounded by experiences of pleasure and suffering, and the same situations can cause both feelings, depending on the situation, child care, recognition and interpersonal relationships.

In the first category, the feelings of pleasure verbalized by the interviewees occur in the work developed with children, participation in the treatment, healing of patients and recognition of family members. In the second category, workers reported that caring for children undergoing palliative treatment and death of patients, performing invasive procedures and organizing work were sources of suffering.

It is noteworthy that none of the interviewees had professional training in the field of paediatric oncology, leaving the question whether this type of training could support better preparation and generate less suffering when dealing with oncological children. Studies that address this topic would be relevant for professional practice, in order to qualify care and preserve workers' mental health.

It is important to emphasize that the knowledge of experiences that generate suffering in nurses contributes to the construction of strategies aimed at the well-being of workers in these units. Thus, it is imperative for generations of collective environments in health institutions where managers and workers are able to express and discuss their ideas and opinions, socially legitimizing the experience of these workers.

Therefore, this study made it possible to expand the question about the well-being of workers who work in these services, instigating managers to the agenda. In addition, it offered subsidies so that the experiences of pleasure and suffering were identified, enabling preventive procedures that offer the possibility of assisting in the perception and intervention in the health / mental illness processes at work.

\section{REFERENCES}

1. Anjos FB, Mendes AM. A psicodinâmica do não-trabalho. Estudo de caso com concurseiros. Rev Laborativa [Internet]. 2015 [cited 2019 Nov 20]; 4(1):35-55. Available from: https://ojs.unesp.br/index.php/rlaborativa/article/view/1074/pdf

2. Kolhs M, Olschowsky A, Barreta NL, Schimerfening J, Vargas RP, Busnello GF. Nursing in urgency and emergency: between the pleasure and suffering. Rev Pesqui: Cuid Fundam. 2017;9(2):422-31. https://doi.org/10.9789/2175-5361.rpcfo.v9.5427 
3. Glanzner $\mathrm{CH}$, Olschowsky A, Hoffmann DA. Autonomia e criatividade no trabalho de equipes de saúde da família no sul do Brasil. Rev Trab (En)Cena. 2017; 2(1):40-9. https://doi.org/10.20873/2526-1487V2N140

4. Souza SKG, Brito MAA, Aguiar IC, Menezes BS. Vivências de prazer e sofrimento no trabalho na percepção de profissionais de recursos humanos. Rev Empreend Inov Tecnol. 2017;4(2):3-29. https://doi.org/10.18256/2359-3539.2017.v4i2.2020

5. Lancman S, Sznelwar LI. Christophe Dejours: da psicopatologia à psicodinâmica do trabalho. 2a ed. Brasília: Paralelo $15 ; 2008$.

6. Viero V, Beck CLC, Coelho APF, Pai DD, Freitas PH, Fernandes MNS. Pediatric oncology nursing workers: the use of defensive strategies at work. Esc Anna Nery [Internet]. 2017 [cited 2020 Jun 29];21(4):e20170058. Available from: https://www.scielo.br/pdf/ean/v21n4/1414-8145ean-2177-9465-EAN-2017-0058.pdf

7. Fonseca MLG, Sá MC. The intangible in the production of care: the exercise of practical intelligence in an oncology ward. Ciênc Saúde Coletiva [Internet]. 2020 [cited 2020 Jun 29];25(1):159-68. Available from: https://www.scielo.br/pdf/csc/v25n1/en_1413-8123-csc-25-01-0159.pdf

8. Ceballos-Vásquez P, Rolo-González G, Hernández-Fernaud E, Díaz-Cabrera D, Paravic-Klijn T, Burgos-Moreno M. Psychosocial factors and mental work load: a reality perceived by nurses in intensive care units. Rev Latino-Am Enfermagem[Internet]. 2015 [cited 2020 Jun 29];23(2):315-22. Available from: https://www.ncbi.nlm.nih.gov/pmc/articles/PMC4459006/pdf/0104-1169-rlae-23-02-00315.pdf

9. Mariano PP, Baldissera VDA, Martins JT, Carreira L. Nursing work organization in long-stay institutions for the elderly: relationship to pleasure and suffering at work. Texto Contexto Enferm[Internet]. 2015 [cited 2020 Jun 29];24(3):756-65. Available from: https://www.scielo.br/pdf/ tce/v24n3/0104-0707-tce-2015001150014.pdf

10. Glanzner $\mathrm{CH}$, Olschowsky A, Dal Pai D, Tavares JP, Hoffman DA. Assessment of indicators and experiences of pain and pleasure in family health teams based on the Psychodynamics of Work. Rev Gaúcha Enferm[Internet]. 2017 [cited 2020 Jun 29];38(4):e2017-0098. Available from: https://www.scielo.br/pdf/rgenf/v38n4/en_1983-1447-rgenf-38-04-e2017-0098.pdf

11. Ministério da Saúde (BR). Resolução n 466, de 12 de dezembro de 2012. Dispõe sobre diretrizes e normas regulamentadoras de pesquisas envolvendo seres humanos [Internet]. Diário Oficial [da] República Federativa do Brasil[Internet], Brasília, DF, 13 jun. 2013 [cited 2019 Jul 11]. Available from: http://conselho.saude.gov.br/resolucoes/2012/Reso466.pdf

12. Minayo MCS. O desafio do conhecimento: pesquisa qualitativa em saúde. São Paulo (SP): Hucitec, 14a edição; 2014.

13. O'Brien BC, Harris IB, Beckman TJ, Reed DA, Cook DA. Standards for reporting qualitative research: a synthesis of recommendations. Acad Med. 2014;89(9):1245-51. https://doi.org/10.1097/acm.0000000000000388

14. Santos JL, Corral-Mulato S, Villela Bueno SM, Robazzi MLCC. Feelings of nurses faced with death: pleasure and suffering from the perspective of psychodynamics of Dejours. Invest Educ Enferm [Internet]. 2016 [cited 2020 Jun 29];34(3):511-17. Available from: http://www.scielo.org. co/pdf/iee/v34n3/2216-0280-iee-34-03-00511.pdf

15. Ribeiro JP, Gomes GC, Mota MS, Silva CD, Fuculo Jr PRB. Productivity of subjectivity and autonomy of nursing professionals in Pediatrics. Rev Bras Enferm[Internet]. 2019 [cited 2020 Jun 29];72(Suppl 1):41-8. Available from: https://www.scielo.br/pdf/reben/v72s1/0034-7167-reben-72-s1-0041.pdf

16. Miorin AD, Camponogara S, Pinno C, Beck CLC, Costa V, Freitas EO. Pleasure and pain of nursing workers at a first aid service. Texto Contexto Enferm [Internet]. 2018 [cited 2020 Jun 29];27(2):e2350015. Available from: https://www.scielo.br/pdf/tce/v27n2/en_0104-0707-tce-2702-e2350015.pdf

17. Lamb FA, Beck CLC, Coelho APF, Vasconcelos RO. Nursing work in a pediatric emergency service: between pleasure and pain. Cogitare Enferm [Internet]. 2019 [cited 2020 Jun 29];24:e59396. Available from: https://revistas.ufpr.br/cogitare/article/download/59396/pdf_en

18. Favero A, Gomes GC. Sofrimento psíquico de profissionais da saúde na área de oncologia. Rev Uningá [Internet]. 2018 [cited 2019 Jul 11];55(1):134-45. Available from: http://revista.uninga.br/index.php/uninga/article/view/47/1658

19. Caram CS, Rezende LC, Montenegro LC, Amaral JM, Brito MJM. Ambiguidades no trabalho da equipe de saúde no contexto de uma unidade de terapia intensiva. Sanare (Sobral) [Internet]. 2016 [cited 2019 Nov 20];15(01):15-24. Available from: https://sanare.emnuvens.com.br/ sanare/article/download/923/552

20. Saifan AR, AI Zoubi AM, Alrimawi I, Melhem O. Exploring the psychological status of Jordanian nurses working with cancer patients. J Nurs Manag. 2019;27(1):215-22. https://doi.org/ 10.1111/jonm.12667

21. Mazer-Gonçalves SM, Valle ERM, Santos MA. Significados da morte de crianças com câncer: vivências de mães de crianças companheiras de tratamento. Estud Psicol (Campinas)[Internet]. 2016 [cited 2020 Jun 29];33(4):613-22. Available from: https://www.scielo.br/pdf/estpsi/ v33n4/0103-166X-estpsi-33-04-00613.pdf

22. Konukbay D, Yildiz D, Suluhan D. Effects of working at the pediatric oncology unit on personal and professional lives of nurses. Int J Caring Sci[Internet]. 2019 [cited 2020 Mar 28];12(2):959-65. Available from: https://internationaljournalofcaringsciences.org/docs/38_konukbay_ original_12_2.pdf

23. Mello BS, Almeida MA, Pruinelli L, Lucena AF. Nursing outcomes for pain assessment of patients undergoing palliative care. Rev Bras Enferm [Internet]. 2019 [cited 2020 Sep 29];72(1):64-72 . https://doi.org/10.1590/0034-7167-2018-0307

24. Cunha MLR, Costa JB, Almeida FA, Maia MM. Crenças do enfermeiro na promoção da autonomia do escolar com câncer frente aos procedimentos de enfermagem. Atas Investig Qualit Saúde [Internet]. 2016 [cited 2019 Nov 20];2:1214-23. Available from: https:// proceedings.ciaiq.org/index.php/ciaiq2016/article/view/876/860

25. Giongo CR, Monteiro JK, Sobrosa GMR. Psicodinâmica do trabalho no Brasil: revisão sistemática da literatura. Temas Psicol[Internet]. 2015 [cited 2019 Nov 20];23(4):803-14. Available from: http://pepsic.bvsalud.org/pdf/tp/v23n4/v23n4a02.pdf 